\title{
The Investigation of Language Teacher Candidates' Self-efficacy and Writing Anxiety in Processual Context
}

\author{
İbrahim Seçkin Aydın \\ Correspondence: İbrahim Seçkin Aydın, Dokuz Eylül Universty Buca Education Faculty, Turkey.
}

Received: November 28, 2018

Accepted: December 20, 2018 Online Published: December 29, 2018

doi:10.11114/jets.v7i1.3793

URL: https://doi.org/10.11114/jets.v7i1.3793

\begin{abstract}
The purpose of this study is to evaluate the self-efficacy perceptions and writing anxiety of the Turkish language teacher candidates that receive training for learning and teaching language in a processual context. The research has been carried out with a total of 113 teacher candidates that study at the Department of Turkish Language in the first $(\mathrm{n}=56)$ and third $(\mathrm{n}=57)$ grades. The reason is that the first graders are beginner and they receive Written Expression classes; and the third graders receive Writing Education classes. The data from both grades have been collected by using the Writing Self-efficacy Perception Scale (WSPS) and the Writing Anxiety Scale (WAS) at the beginning and at the end of the term. The collected data have been analyzed both in respective class levels and by comparing to the other class level. The result of the research shows that the writing anxiety has decreased and the writing self-efficacy perception has increased in the first grader candidates. Whereas in the third grader candidates, the writing anxiety has increased and the writing self-efficacy perception has decreased. This has been interpreted as the professional awareness of the candidates increases depending on the grade level. Another result of the research is that the revision and editing (RE) factor in the writing process is higher in the female candidates than the male candidates. The findings obtained in the research bear a resemblance to the literature in some aspects, and differ from the literature in some aspects.
\end{abstract}

Keywords: writing education, writing self-efficacy perception, writing anxiety, language teacher candidates

\section{Introduction}

Writing requires various sub-skills and it can also be considered as the most difficult linguistic skill to develop as it is a versatile and complicated linguistic skill (Espin, Weissenburger \& Benson, 2004, 55). Writing process requires a set of mental processes before a physical action. From this aspect, writing is transferring ideas depending on a layout via symbols. In classic writing education, a good writing has been expected to be up to the mark in terms of appearance and content, and upon this expectation, assessment and evaluation processes have been carried out.

Since the 1970s, various models (Hayes \& Flower, 1980; Bereiter \& Scardamalia, 1987; Hayes 1996, The Zimmerman \& Risemberg 1997, Bishop \& Ostrom 1994; Grabe \& Kaplan, 1996; McCutchen, 2000; Prior, 2006) have been developed in teaching of writing as a skill and how to train a good writer has been dwelled on. In these researches, writing have first been evaluated by taking stages of text generation and textuality into consideration in the light of linguistic studies, and then investigated in the context of psychology and pedagogy with regards to mental processes of writing.

Researches aimed at writing created a new field of study based on the Social Learning Theory of Bandura (1977) and have been investigated in the spotlight of writing "self-efficacy". In this context, self-efficacy and anxiety studies (Bloom, 1980; Brand \& Powell, 1986; Daly, 1985; Selfe, 1985) about writing has gained a sudden intensity since the 1980s.

\subsection{Writing Self-efficacy and Writing Anxiety}

According to Bandura (1977:129), the act of writing is a familiar example of a behavior that is continuously self-regulated through evaluative self-reinforcement. Authors don't need someone sitting at their sides selectively reinforcing each written statement until a satisfactory manuscript is produced. Rather, they possess a standard of what constitutes an acceptable piece of work. Bandura (1977) states that ideas are generated and phrased in thought several times before anything is committed to paper. Initial constructions are successively revised until authors are satisfied with what they have written. The more exacting the personal standards, the more extensive are the corrective improvements. Self-editing often exceeds external requirements of what would be acceptable to others. 
According to the Social Learning Theory, this belief in one's ability to complete a task comes from four sources: (a) past performances or mastery experiences, (b) vicarious experiences through observing a modeled behavior, (c) interpretations of one's psychological and affective state, and (d) verbal persuasion (Bandura, 1977; Pajares, 2003).

Self-efficacy, in addition to being intrinsic to a specific context and field (Bandura, 2006; Schunk \& Pajares, 2002); can differ according to school, other environmental media and even academic field (Frank Webb, Vandiver, \& Jeung, 2016). In other words, both the sources that self-efficacy rely on and types of self-efficacy vary.

In modern education process; students' knowing themselves, awareness stages, self-efficacy perceptions and metacognitive perceptions are taken into consideration in addition to teaching. Among these, self-efficacy perception has become a special research subject of writing in literature. According to Schunk (2003), those who feel more efficient in learning process or in fulfilling a duty, make efforts for longer and reach a higher level than those who suspect their learning skills when run into difficulties. Thus, increasing writing self-efficacy has been considered an important variable for students to overcome difficulties. The biggest recognition in the literature is that increasing self-efficacy results in increasing performance. While this opinion basically relies on Bandura $(1977,1997)$ the studies afterwards have supported this hypothesis. The results of the studies (Daly, 1978; Pajares \& Johnson, 1996; Prat-Sala \& Redford, 2012; Yusuf, 2011) that applied on various age groups from primary school to university have revealed a positive relation between increasing writing self-efficacy and writing performance.

On the other hand, the leading study that is related to writing self-efficacy is writing anxiety. According to Daly and Miller (1975), writing anxiety has three main reasons and these are; fear of negative critics toward the text (evaluation apprehension), fear of being evaluated personally (stress apprehension), and fear of failing writing classes (product apprehension).

Writing anxiety is an impediment to effective writing for many people. These individuals report that they are afraid of writing and that they avoid writing, even though such behavior means poorer performance at school and at work. A large group of people feel apprehensive about committing words to paper, experience intense anxiety while writing, and try to avoid writing at all costs (Salovey \& Haar, 1990: 514). Research results (Huerta, Goodson, Beigi \& Chlup, 2017; Singh, \& Rajalingam, 2012; Stewart, Seifert, \& Rolheiser, 2015; Woodrow, 2011; Martinez, Kock, \& Cass, 2011) show that those who have high writing anxiety have low self-efficacy perceptions, and those who have low writing anxiety have high self-efficacy perceptions. Likewise, Bonifacci, Candria and Contento (2008) have come to the conclusion that the children who carry the risk of depression have more spelling errors in writing.

Writing self-efficacy and writing anxiety, which have a negative relationship with one another, are in the spotlight of this research. The primary purpose of this study is to investigate whether Turkish language teacher candidates, who will acquire teaching language as a profession, experience a change during learning process in the contexts of writing self-efficacy and writing anxiety. Both in-class level developments and the relations of two different class levels of the first grader and third grader participants have been determined. The most important reason for choosing these two class levels is that the first graders receive "Written Expression" classes; and the third graders receive "Writing Education" classes at the Department of Turkish Language. While Written Expression class is aimed at improving teacher candidates' own writing skills; Writing Education class is not only aimed at improving own writing skills, but also relies on a process that includes theoretical and applied studies that will be used as teaching techniques for writing education in the future. Within this scope; this study seeks answers for the following questions:

1. Is there a relation between writing anxiety level pretest scores, and writing self-efficacy and writing self-efficacy sub-factor pretest scores of teacher candidates?

2. Is there a relation between writing anxiety posttest scores, and writing self-efficacy and writing self-efficacy sub-factor posttest scores of teacher candidates?

3. Do writing anxiety, and writing self-efficacy and writing self-efficacy sub-factor pretest scores of teacher candidates differ by gender?

4. Do writing anxiety, and writing self-efficacy and writing self-efficacy sub-factor posttest scores of teacher candidates differ by gender?

5. Do writing anxiety, and writing self-efficacy and writing self-efficacy sub-factor pretest scores of teacher candidates differ by class level?

6. Do writing anxiety, and writing self-efficacy and writing self-efficacy sub-factor posttest scores of teacher candidates differ by class level?

7. Is there a difference between writing anxiety, and writing self-efficacy and writing self-efficacy sub-factor pretest-posttest scores of first grader and third grader teacher candidates? 
Determining the change in the writing self-efficacy and writing anxiety of the participants, and whether a difference comes about between class levels are the fundamental points of this research. Therefore, whether writing self-efficacy and writing anxiety of teacher candidates differ by the knowledge and the experience they gain in time has been determined correspondingly.

\section{Method}

This study has been carried out in order to determine the relations and differences between writing self-efficacy perception and writing anxiety of first grader and third grader teacher candidates that study at the Department of Turkish Language, based on quantitative research.

\subsection{Working Group}

The working group of this research is constituted of 64 female and 49 male teacher candidates that study at Dokuz Eylul University, Buca Faculty of Education, Department of Turkish Language in the 2017-2018 school year. At the beginning of the fall semester, first grader $(n=56)$ and third grader $(n=57)$ candidates have been given the writing anxiety and writing self-efficacy scale, and the same process has been repeated at the end of the spring semester. In order to help the identification, the candidates have been asked to add the last three digits of their numbers to the scale tool. The participants who attended both stages of the scale tool at the beginning and at the end of the semester have been identified and those who didn't provide their numbers and didn't attend both of the stages have been removed from the dataset. Also, three participants with extreme values have been removed from the dataset. Thus, 113 teacher candidates that participated in pre and final applications of the research have constituted the working group of the research.

\subsection{Scale Tools}

\subsubsection{Writing Anxiety Scale (WAS)}

The WAS that has been utilized in the research has been developed by Karakaya and Ulper (2011) with the data collected from 202 third graders who study at Ondokuz Mayıs University, Faculty of Education, Primary School Teaching, Elementary Mathematics Teaching and Turkish Language Teaching departments. The scale is constituted by 35 articles and one dimension. Greater scores are a sign of greater anxiety level; and lower scores indicate lower anxiety levels. Cronbach's alpha reliability coefficient of the scale has been detected 0.97 . Single subdimension clarifies $48.90 \%$ of total variance.

\subsubsection{Writing Self-efficacy Perception Scale (WSPS)}

Another scale used in the research is the WSPS, which has been developed by Aydın, Innal, Batar and Cakır (2013) for teacher candidates and constitutes of three factors. These factors are Writing Preparation (WP), Manuscript Composition (MC), and Revision and Editing (RE). The first factor clarifies 7,2\% of total variance (12 articles; Writing Preparation), the second factor clarifies 33,6\% of total variance (33 articles; Manuscript Composition), and the third factor clarifies 3,9\% of total variance (9 articles; Revising and Editing Manuscript). On sub-scales level, factor load values have been observed to vary between .42 and .68 in the "Writing Preparation" dimension; between .37 and .67 in the "Manuscript Composition" dimension; and between .60 and .81 in the "Revising and Editing Manuscript" dimension. The first factor Cronbach alpha coefficient has been calculated .88, the second factor .96 , and the third factor .89 . The whole scale has .96 alpha coefficient.

\subsection{Data Analysis}

After investigating the missing and extreme values, means assigned for missing values and the three participants with extreme values (subjects 17, 53 and 76) have been removed from the dataset.

While calculating correlations, normality distribution of total scores has been investigated in order to decide on which analysis to use. The scores of the pretest and posttest of the anxiety scale have been found non-normally distributed and the correlations calculated by Spearman correlation coefficient.

In order to decide on which analysis to use while calculating the difference from gender and class level, normality distribution of total scores has been investigated both in gender subgroups and class level subgroups. As the scores found non-normally distributed in some subgroups, the Mann Whitney $U$ test has been decided to utilize out of nonparametric techniques. Likewise, in order to specify the differences between pretests and posttests according to class level, the Wilcoxon test has been decided to utilize out of nonparametric techniques.

\section{Findings and Remarks}

Based on the first subproblem sentence of the research, the relation between writing and self-efficacy pretest scores of the participants has been provided in Table 1 . 
Table 1 . The relations between anxiety pretest scores and self-efficacy pretest scores

\begin{tabular}{llllll}
\hline & & WSP_pre & WP_pre & MC_pre & RE_pre \\
\hline WAS & Spearman's rho &,$- 315^{* *}$ &,$- 194^{*}$ &,$- 307^{* *}$ &,$- 194^{*}$ \\
& $\mathrm{p}$ &, 001 &, 040 &, 001 &, 040 \\
& $\mathrm{~N}$ & 113 & 113 & 113 & 113 \\
\hline
\end{tabular}

When Table 1 is analyzed, there is a negative direction moderate-level statistically significant correlation between WAS pretest scores and writing self-efficacy (WSP) pretest scores (rho=-0.315, $\mathrm{p}<0.05$ ) and writing order pretest scores $($ rho $=-0.307, \mathrm{p}<0.05)$. There is a low-level statistically significant correlation between WAS pretest scores and WP pretest scores $(r h o=-0.194, \mathrm{p}<0.05)$ and RE pretest scores $(r h o=-0.194, \mathrm{p}<0.05)$

Based on the second subproblem sentence of the research, the relation between WAS and WSP posttest scores of the participants has been provided in Table 2 .

Table 2. The relations between WAS posttest scores and self-efficacy posttest scores

\begin{tabular}{llllll}
\hline & & WSP_post & WP_post & MC_post & RE_post \\
\hline WAS_post & Spearman's rho &,$- 516^{* * *}$ &,$- 499^{* * *}$ &,$- 506^{* * *}$ &,$- 248^{* *}$ \\
& $\mathrm{p}$ &, 000 &, 000 &, 000 &, 008 \\
& $\mathrm{~N}$ & 113 & 113 & 113 & 113 \\
\hline
\end{tabular}

When Table 2 is analyzed, there is a negative direction moderate-level statistically significant correlation between WAS posttest scores and WSP posttest scores (rho=-0.516, p<0.05), WP posttest scores (rho=-0.499, p<0.05) and MC posttest scores $(\mathrm{rho}=-0.506, \mathrm{p}<0.05)$. There is a low-level statistically significant correlation between WAS posttest scores and $\mathrm{MC}$ posttest scores (rho=-0.248, $\mathrm{p}<0.05)$.

Based on the third subproblem sentence of the research, whether the WAS and WSP pretest scores of the participants differ by gender has been provided in Table 3.

Table 3. Pretest score differences by gender

\begin{tabular}{|c|c|c|c|c|c|c|}
\hline & gender & $\mathrm{N}$ & Mean rank & Total rank & $\mathrm{U}$ & $\mathrm{p}$ \\
\hline \multirow[t]{3}{*}{ WAS_pre } & Female & 64 & 57,12 & 3655,50 & 1560,500 & ,965 \\
\hline & Male & 49 & 56,85 & 2785,50 & & \\
\hline & Total & 113 & & & & \\
\hline \multirow[t]{3}{*}{ WSP_pre } & Female & 64 & 64,51 & 4128,50 & 1087,500 & ,005 \\
\hline & Male & 49 & 47,19 & 2312,50 & & \\
\hline & Total & 113 & & & & \\
\hline \multirow[t]{3}{*}{ WP_pre } & Female & 64 & 62,60 & 4006,50 & 1209,500 & ,038 \\
\hline & Male & 49 & 49,68 & 2434,50 & & \\
\hline & Total & 113 & & & & \\
\hline \multirow[t]{3}{*}{ MC_pre } & Female & 64 & 61,25 & 3920,00 & 1296,000 & , 115 \\
\hline & Male & 49 & 51,45 & 2521,00 & & \\
\hline & Total & 113 & & & & \\
\hline \multirow[t]{3}{*}{ RE_pre } & Female & 64 & 67,69 & 4332,00 & 884,000 & ,000 \\
\hline & Male & 49 & 43,04 & 2109,00 & & \\
\hline & Total & 113 & & & & \\
\hline
\end{tabular}

When Table 3 is analyzed, WAS $(\mathrm{U}=1560.5, \mathrm{p}>0.05)$ and MC $(\mathrm{U}=1296, \mathrm{p}>0.05)$ pretest scores don't seem to have significant differences by gender. Whereas WSP $(U=1087.5, p<0.05), W P(U=1209.5, p<0.05)$ and $R E(U=884, p<0.05)$ pretest scores differ significantly by gender. WSP, WP and RE pretest scores of the female are higher than the male by a statistically significant margin.

Based on the fourth subproblem sentence of the research, whether the WAS and WSP posttest scores of the participants differ by gender has been provided in Table 4 . 
Table 4. Posttest score differences by gender

\begin{tabular}{|c|c|c|c|c|c|c|}
\hline & gender & $\mathrm{N}$ & Mean rank & Total rank & $\mathrm{U}$ & $\mathrm{p}$ \\
\hline \multirow[t]{3}{*}{ WAS_post } & Female & 64 & 54,96 & 3517,50 & 1437,500 &, 450 \\
\hline & Male & 49 & 59,66 & 2923,50 & & \\
\hline & Total & 113 & & & & \\
\hline \multirow[t]{3}{*}{ WSP_post } & Female & 64 & 60,49 & 3871,50 & 1344,500 & ,195 \\
\hline & Male & 49 & 52,44 & 2569,50 & & \\
\hline & Total & 113 & & & & \\
\hline \multirow[t]{3}{*}{ WP_post } & Female & 64 & 58,56 & 3748,00 & 1468,000 & ,562 \\
\hline & Male & 49 & 54,96 & 2693,00 & & \\
\hline & Total & 113 & & & & \\
\hline \multirow[t]{3}{*}{ MC_post } & Female & 64 & 58,12 & 3719,50 & 1496,500 & 679 \\
\hline & Male & 49 & 55,54 & 2721,50 & & \\
\hline & Total & 113 & & & & \\
\hline \multirow[t]{3}{*}{ RE_post } & Female & 64 & 69,98 & 4479,00 & 737,000 & ,000 \\
\hline & Male & 49 & 40,04 & 1962,00 & & \\
\hline & Total & 113 & & & & \\
\hline
\end{tabular}

When Table 4 is analyzed, WAS ( $U=1437, \mathrm{p}>0.05)$, WSP $(\mathrm{U}=1344.5, \mathrm{p}>0.05)$, WP $(\mathrm{U}=1468, \mathrm{p}>0.05)$ and MC $(\mathrm{U}=1496.5, \mathrm{p}>0.05)$ posttest scores don't seem to have significant differences by gender. Whereas the RE scores differ significantly by gender $(U=737, p<0.05)$. RE scores of the female are higher than the post-writing scores of the male by a statistically significant margin.

Based on the fifth subproblem sentence of the research, whether the pretest scores of the participants differ by class level has been provided in Table 5 .

Table 5. Pretest score differences by class level

\begin{tabular}{|c|c|c|c|c|c|c|}
\hline & class & $\mathrm{N}$ & Mean rank & Total rank & $\mathrm{U}$ & $\mathrm{p}$ \\
\hline \multirow[t]{3}{*}{ WAS_pre } & 1 & 57 & 62,52 & 3563,50 & 1281,500 & ,071 \\
\hline & 3 & 56 & 51,38 & 2877,50 & & \\
\hline & Total & 113 & & & & \\
\hline \multirow{3}{*}{ WSP_pre } & 1 & 57 & 55,90 & 3186,50 & 1533,500 & .720 \\
\hline & 3 & 56 & 58,12 & 3254,50 & & \\
\hline & Total & 113 & & & & \\
\hline \multirow[t]{3}{*}{ WP_pre } & 1 & 57 & 62,96 & 3589,00 & 1256,000 & ,051 \\
\hline & 3 & 56 & 50,93 & 2852,00 & & \\
\hline & Total & 113 & & & & \\
\hline \multirow[t]{3}{*}{ MC_pre } & 1 & 57 & 56,11 & 3198,00 & 1545,000 & ,770 \\
\hline & 3 & 56 & 57,91 & 3243,00 & & \\
\hline & Total & 113 & & & & \\
\hline \multirow[t]{3}{*}{ RE_pre } & 1 & 57 & 49,28 & 2809,00 & 1156,000 & ,011 \\
\hline & 3 & 56 & 64,86 & 3632,00 & & \\
\hline & Total & 113 & & & & \\
\hline
\end{tabular}

When Table 5 is analyzed, WAS ( $\mathrm{U}=1282.5, \mathrm{p}>0.05)$, WSP $(\mathrm{U}=1533.5, \mathrm{p}>0.05)$, WP $(\mathrm{U}=1256, \mathrm{p}>0.05)$ and MC $(\mathrm{U}=1545, \mathrm{p}>0.05)$ scores don't seem to have significant differences by class level. Whereas the RE scores differ significantly by class level $(\mathrm{U}=1156, \mathrm{p}<0.05)$. The RE pretest scores of the third graders are higher than the RE pretest scores of the first graders by a statistically significant margin.

Based on the sixth subproblem sentence of the research, whether the posttest scores of the participants differ by class level has been provided in Table 6 . 
Table 6. Posttest score differences by class level

\begin{tabular}{|c|c|c|c|c|c|c|}
\hline & class & $\mathrm{N}$ & Mean rank & Total rank & $\mathrm{U}$ & $\mathrm{p}$ \\
\hline \multirow[t]{3}{*}{ WAS_post } & 1 & 57 & 50,41 & 2873,50 & 1220,500 & 031 \\
\hline & 3 & 56 & 63,71 & 3567,50 & & \\
\hline & Total & 113 & & & & \\
\hline \multirow[t]{3}{*}{ WSP_post } & 1 & 57 & 69,43 & 3957,50 & 887,500 & 000 \\
\hline & 3 & 56 & 44,35 & 2483,50 & & \\
\hline & Total & 113 & & & & \\
\hline \multirow[t]{3}{*}{ WP_post } & 1 & 57 & 71,99 & 4103,50 & 741,500 & , 000 \\
\hline & 3 & 56 & 41,74 & 2337,50 & & \\
\hline & Total & 113 & & & & \\
\hline \multirow[t]{3}{*}{ MC_post } & 1 & 57 & 69,89 & 3984,00 & 861,000 & 000 \\
\hline & 3 & 56 & 43,88 & 2457,00 & & \\
\hline & Total & 113 & & & & \\
\hline \multirow[t]{3}{*}{ RE_post } & 1 & 57 & 55,84 & 3183,00 & 1530,000 & ,704 \\
\hline & 3 & 56 & 58,18 & 3258,00 & & \\
\hline & Total & 113 & & & & \\
\hline
\end{tabular}

When Table 6 is analyzed, WAS $(U=1220.5, p<0.05)$, WSP $(U=887.5, p<0.05)$, WP $(U=741.5, p<0.05)$ and MC $(U=861$, $\mathrm{p}<0.05)$ scores seem to have significant differences by class level. The WAS levels of the third graders are higher than the first graders by a statistically significant margin. The WSP, WP and MC posttest scores of the first graders are higher than the third graders by a statistically significant margin. Whereas the RE scores doesn't differ significantly by class levels $(\mathrm{U}=1530, \mathrm{p}>0.05)$.

Based on the seventh subproblem sentence of the research, whether there is a difference between the first and the third grader pretest-posttest scores of the WAS and the WSP perceptions of teacher candidates has been provided in Table 7 and 8 .

Table 7. Pretest-posttest score differences of the first graders

\begin{tabular}{|c|c|c|c|c|c|c|}
\hline & & $\mathrm{N}$ & Mean Rank & Total Rank & $\mathrm{Z}$ & $\mathrm{p}$ \\
\hline \multirow[t]{4}{*}{ WAS_post - WAS_pre } & Negative Ranks & 35 & 29,66 & 1038,00 & $-2,246^{\mathrm{c}}$ &, 025 \\
\hline & Positive Ranks & 20 & 25,10 & 502,00 & & \\
\hline & Equal Ranks & 2 & & & & \\
\hline & Total & 57 & & & & \\
\hline \multirow[t]{4}{*}{ WSP_post - WSP_pre } & Negative Ranks & 17 & 24,53 & 417,00 & $-3,254^{\mathrm{d}}$ & ,001 \\
\hline & Positive Ranks & 40 & 30,90 & 1236,00 & & \\
\hline & Equal Ranks & 0 & & & & \\
\hline & Total & 57 & & & & \\
\hline \multirow[t]{4}{*}{ WP_post - WP_pre } & Negative Ranks & 19 & 22,95 & 436,00 & $-2,478^{d}$ & ,013 \\
\hline & Positive Ranks & 34 & 29,26 & 995,00 & & \\
\hline & Equal Ranks & 4 & & & & \\
\hline & Total & 57 & & & & \\
\hline \multirow[t]{4}{*}{ MC_post - MC_pre } & Negative Ranks & 18 & 21,53 & 387,50 & $-3,206^{\mathrm{d}}$ & ,001 \\
\hline & Positive Ranks & 37 & 31,15 & 1152,50 & & \\
\hline & Equal Ranks & 2 & & & & \\
\hline & Total & 57 & & & & \\
\hline \multirow[t]{4}{*}{ RE_post - RE_pre } & Negative Ranks & 16 & 23,28 & 372,50 & $-2,727^{d}$ & ,006 \\
\hline & Positive Ranks & 35 & 27,24 & 953,50 & & \\
\hline & Equal Ranks & 6 & & & & \\
\hline & Total & 57 & & & & \\
\hline
\end{tabular}

c. Based on Positive Ranks.

d. Based on Negative Ranks.

When Table 7 is analyzed, a significant difference is seen between all pretest-posttest scores of all the total scores of the first graders. A statistically significant difference is seen between the WAS pretest-posttest scores $(\mathrm{Z}=-2.246$, $\mathrm{p}<0.05)$. The WAS pretest scores $(=91.04)$ are higher than the posttest scores $(=79.89)$ by a statistically significant margin. A statistically significant difference is seen between the WSP pretest-posttest scores $(Z=-3.254, p<0.05)$. The WSP posttest scores $(=211.30)$ are higher than the pretest scores $(=197.53)$ by a statistically significant margin. A statistically significant difference is seen between the WP pretest-posttest scores $(Z=-2.478, p<0.05)$. The WP posttest scores $(=47.23)$ are higher than the pretest scores $(=44.56)$ by a statistically significant margin. A statistically significant difference is seen between the MC pretest-posttest scores $(Z=-3.206, p<0.05)$. The MC posttest scores $(=127.91)$ are 
higher than the pretest scores $(=118.95)$ by a statistically significant margin. A statistically significant difference is seen between the post-writing pretest-posttest scores $(\mathrm{Z}=-2.727, \mathrm{p}<0.05)$. The post-writing posttest scores $(36.16)$ are higher than the pretest scores (34.02) by a statistically significant margin.

Table 8. Pretest-posttest score differences of the third graders

\begin{tabular}{|c|c|c|c|c|c|c|}
\hline & & $\mathrm{N}$ & Mean Rank & Total Rank & $\mathrm{Z}$ & $\mathrm{p}$ \\
\hline \multirow[t]{4}{*}{ WAS_post - WAS_pre } & Negative Ranks & 20 & 18,95 & 379,00 & $-3,419^{\mathrm{c}}$ & 001 \\
\hline & Positive Ranks & 36 & 33,81 & 1217,00 & & \\
\hline & Equal Ranks & 0 & & & & \\
\hline & Total & 56 & & & & \\
\hline \multirow[t]{4}{*}{ WSP_post - WSP_pre } & Negative Ranks & 38 & 30,08 & 1143,00 & $-3,126^{\mathrm{d}}$ & ,002 \\
\hline & Positive Ranks & 17 & 23,35 & 397,00 & & \\
\hline & Equal Ranks & 1 & & & & \\
\hline & Total & 56 & & & & \\
\hline \multirow{4}{*}{ WP_post - WP_pre } & Negative Ranks & 35 & 27,51 & 963,00 & $-1,902^{\mathrm{d}}$ & 057 \\
\hline & Positive Ranks & 19 & 27,47 & 522,00 & & \\
\hline & Equal Ranks & 2 & & & & \\
\hline & Total & 56 & & & & \\
\hline \multirow[t]{4}{*}{ MC_post - MC_pre } & Negative Ranks & 34 & 31,87 & 1083,50 & $-3,259^{\mathrm{d}}$ & 001 \\
\hline & Positive Ranks & 19 & 18,29 & 347,50 & & \\
\hline & Equal Ranks & 3 & & & & \\
\hline & Total & 56 & & & & \\
\hline \multirow[t]{4}{*}{ RE_post - RE_pre } & Negative Ranks & 30 & 24,72 & 741,50 & $-1,289^{\mathrm{d}}$ & 198 \\
\hline & Positive Ranks & 19 & 25,45 & 483,50 & & \\
\hline & Equal Ranks & 7 & & & & \\
\hline & Total & 56 & & & & \\
\hline
\end{tabular}

c. Based on Negative Ranks.

d. Based on Positive Ranks.

When Table 8 is analyzed, a statistically significant difference cannot be seen between the WP $(Z=-1.902, p>0.05)$ and the RE $(Z=-1.289, p>0.05)$ pretest-posttest scores of the third graders. A statistically significant difference is seen between the WAS pretest-posttest scores $(Z=-3.419, \mathrm{p}<0.05)$. The WAS posttest scores $(=91.46)$ are higher than the pretest scores $(=81.46)$ by a statistically significant margin. A statistically significant difference is seen between the WSP pretest-posttest scores $(\mathrm{Z}=-3.216, \mathrm{p}<0.05)$. The WSP pretest scores $(=198)$ are higher than the posttest scores $(=189.86)$ by a statistically significant margin. A statistically significant difference is seen between the MC pretest-posttest scores $(\mathrm{Z}=-3.216, \mathrm{p}<0.05)$. The $\mathrm{MC}$ pretest scores $(=119.27)$ are higher than the posttest scores $(=113.30)$ by a statistically significant margin.

\section{Conclusion and Discussion}

This research has been carried out with the data collected from the tools that scale self-efficacy perceptions and anxieties of the Turkish Language teacher candidates towards writing at the beginning and at the end of the first and the third grade. The most distinctive feature of this study compared to other studies in the existing literature is the analysis of development levels of the participants with the help of the evaluations conducted at the beginning and at the end of the school year. The analyses carried out within this scope have led to remarkable results.

The first result obtained is that there is a negative direction moderate-level statistically significant relation between the writing anxiety (WAS) pretest scores and the writing self-efficacy (WSP) pretest scores and the manuscript composition (MC) pretest scores. Whereas between the anxiety pretest scores, writing preparation (WP) pretest scores, revising and editing (RE) pretest scores, there is a low-level statistically significant relation. When posttests are analyzed, there is a negative direction moderate-level statistically significant relation between writing anxiety posttest scores and writing self-efficacy posttest scores, and between writing preparation posttest scores and manuscript composition posttest scores. Between writing anxiety posttest scores and revising and editing posttest scores however, there is a low-level statistically significant relation. Accordingly, it can be said that the participants with low writing anxiety get high scores from writing self-efficacy and its subfactors. These results bear a resemblance to other researches (Huerta, Goodson, Beigi \& Chlup, 2017; Singh, \& Rajalingam, 2012; Stewart, Seifert, \& Rolheiser, 2015; Woodrow, 2011; Martinez, Kock, $\&$ Cass, 2011) in the literature.

The second result obtained from the research is that writing self-efficacy, writing preparation, revising and editing pretest scores of the female participants are higher than the male participants. Whereas in the posttest, only revising and 
editing scores have a significant difference on behalf of the female participants. In terms of writing anxiety, some of the researches (Çakmak \& Civelek 2013; Karahan, 2017; Hakkoymaz, 2017, Karakaya \& Ülper, 2011) in different levels show no difference by gender, whereas in some researches (Zorbaz, 2011; Huerta, Goodson, Beigi \& Chlup, 2017; Cocuk, Yelken \& Özer, 2016; Berk \& Ünal, 2017; 25, Güneyli, 2016) significant differences can be seen. As for this research, writing anxiety hasn't differed by gender neither in pretest nor in posttest. When the studies that intended writing self-efficacy of teacher candidates according to gender are examined, there are results with and without differences just like in writing anxiety. For instance, in the study of Pajares and Johnson (1996) on ninth grader high school students, there is no difference in terms of skill or performance but it has been stated that the female students reported lower levels of writing self-efficacy. Whereas in the study of Pajares and Valiante (1999) on secondary school students, there is no difference in writing self-efficacy by gender. In another research by Pajares, Johnson and Usher (2007) female students reported stronger writing self-efficacy and receiving better marks by their teachers.

Another result obtained from the research is that revision and editing scores differ significantly according to class levels. Revision and editing pretest scores of the third graders are higher than the revision and editing pretest scores of the first graders by a statistically significant margin. As for posttests; writing anxiety, writing self-efficacy, writing preparation and manuscript composition scores differ significantly according to class level, and anxiety levels of the third graders are higher than the first graders. Self-efficacy, writing preparation and manuscript composition posttest scores of the first graders are higher than the third graders by a statistically significant margin. Herein, first grader teacher candidates with lower writing anxiety and higher self-efficacy perception than the third grader constitutes one of the striking results of the research. When the studies aimed at writing anxiety of the Turkish language teacher candidates in the literature are examined; Iseri and Unal (2012) have determined that candidates had low writing anxiety; whereas Karahan (2017) has determined that candidates had high writing anxiety.

One of the most important recognition regarding self-efficacy is about academic level. The expectation of the higher academic level and age, the higher self-efficacy and the lower anxiety has been rendered false in the present study. According to the study of Pajares and Valiante (1999) on writing self-efficacy level, $6^{\text {th }}$ graders have higher writing self-efficacy than $7^{\text {th }}$ and $8^{\text {th }}$ graders. Pajares, Johnson and Usher (2007) have also stated in their study that primary school students had higher self-efficacy perception than secondary and high school students.

Final stage of the study has been to investigate individual development of each class level. For the first graders, there is a significant difference between pretest-posttest scores for all total scores. Writing anxiety pretest scores are higher than the posttest scores by a statistically significant margin. There is a statistically significant difference between writing self-efficacy pretest-posttest scores, as well. Writing self-efficacy posttest scores are higher than the pretest scores by a statistically significant margin. A similar situation has been observed for the three subfactors of writing self-efficacy; posttest scores determined higher than the pretest scores. Therefore, it can be said that writing anxiety decreases and writing self-efficacy increases within the process, resulting in a development of a positive direction. For the third graders, there is a statistically significant difference between writing self-efficacy pretest-posttest scores. But writing self-efficacy pretest scores are higher than the posttest scores by a statistically significant margin, contrary to the first graders. Writing anxiety posttest scores are higher than the pretest scores by a statistically significant margin. Pretest scores of manuscript composition, one of the subfactors of writing, are higher than the posttest scores by a statistically significant margin. Correspondingly, it can be said for the third graders that writing anxiety increases and writing self-efficacy perception decreases within the process.

The study of Erdogan (2017) aimed at decreasing writing anxiety, has reached to the conclusion that cooperative writing activities decreases writing anxiety of teacher candidates. The experimental study of Topuzkanamis (2015) intended for first grader teacher candidates of Turkish language, has reached to the conclusion that teaching strategies decreases writing anxiety. Stewart, Seifert and Rolheiser (2015) have concluded that using metacognitive strategies increases self-efficacy perceptions and decreases writing anxiety of university students. Balta (2018) has concluded that students with low writing anxiety are more successful at argumentative writing compared to their colleagues with moderate or high anxiety levels.

Considering the conclusions above, the conclusions of the present study bear a resemblance to the other studies in the literature, as well as some conclusions with no agreement. Especially the increase in the writing self-efficacy and the decrease in the writing anxiety of the first grader teacher candidates after the evaluations carried out at the beginning and at the end of the school year are expected results. But the decrease in the writing self-efficacy and the increase in the writing anxiety of the third graders are considered unexpected results. First grader and third grader candidates' regarding themselves sufficient can be evaluated with internal dynamics of education process. The criteria of the first grader candidates for their self-efficacy perceptions in writing process are directly about the text production process itself. Especially the first grader candidates that receive written expression classes, have gone into the effort of decreasing writing anxiety and increasing writing self-efficacy perception by realizing their own development levels. It 
is probable for the third grader candidates to reveal new criteria for their own writing skills considering the increasing background knowledge with the education they receive. Hence the criteria for producing a well written text increase in the third-grade level. Realizing that writing is not an easy process with the knowledge and experience gained can be considered as a variable that increases writing anxiety. At this point, it is possible to regard decreased self-efficacy of the third graders as increasing awareness rather than a negative case. It is necessary to focus on the reasons of these results with the same or similar participants with another research. Also, the changes in the self-efficacy and anxiety levels must be actualized by comparing to writing performances of the participants, as well.

It is new subject of study that gender scores, especially the posttest scores of revision and editing, a subfactor of writing self-efficacy, are on behalf of the female participants. Detecting the suppressive variables underlying the success of female participants in self-regulation, an important stage of self-evaluation, required to be scrutinized in sociocultural dimensions, as well as in educational sciences.

With reference to the conclusions of this study, new studies must be carried to account for the reasons of the increase in writing anxiety and the decrease in writing self-efficacy of the candidates who will possess teaching language as a profession in the future. Also, the relations between writing skill and writing self-efficacy and writing anxiety must be identified by carrying out evaluations on writing performances of the participants within the process. Because the difficulties faced by participants in their own writing skills also indicate the possible problems they will face while performing teaching as a profession.

\section{References}

Ateş, A., \& Akaydın, Ş. (2015). Ortaokul öğrencilerinin yazma kaygılarının incelenmesi: Malatya ili örneği. Dil ve Edebiyat Ĕgitimi Dergisi,16, 24-38.

Aydın, İ. S., İnnalı, H. Ö., Batar, M., \& Çakır, H. (2013). Öğretmen adaylarının yazılı anlatım öz yeterliklerine ilişkin ölçek geliştirme çalışması. Journal of Turkish Studies, 8(8), 139-160. https://doi.org/10.7827/TurkishStudies.4978

Balta, E. E. (2018). The relationships among writing skills, writing anxiety and metacognitive awareness. Journal of Education and Learning, 7(3), 233-241. https://doi.org/10.5539/jel.v7n3p233

Bandura, A. (1977). Social learning theory. Prentice-Hall International UK

Bandura, A. (1997). Self-efficacy in Changing Societies, Cambridge University Press UK

Bandura, A. (2006). Guide for constructing self-efficacy scales. In F. Pajares \& T. Urdan (Eds.), Self-efficacy beliefs of adolescents (pp. 307-337). Greenwich, CT: Information Age.

Bereiter, Carl and Marlene Scardamalia. 1987. Knowledge telling and knowledge transforming in written communication . In: Sheldon Rosenberg (ed.), Advances in Applied Sociolinguistics, 142-175. Cambridge, UK: Cambridge University Press.

Berk, R. R., \& Ünal, E. (2017). Comparison of Writing Anxiety and Writing Dispositions of Sixth, Seventh and Eighth Grade Students. International Journal of Instruction, 10(01), 237-254. https://doi.org/10.12973/iji.2017.10115a

Bishop, W., \& Ostrom, H. A. (1994). Colors of a different horse: Rethinking creative writing theory and pedagogy. Urbana, Ill: National Council of Teachers of English.

Bloom, L. Z. (1980). Identifying and reducing writing anxiety, Part II: Writing anxiety workshops. In D. Butturff (Ed.), The psychology of composition. Akron: University of Akron Press.

Bloom, L. Z. (1985). Anxious writers in context: Graduate school and beyond. In M. Rose (Ed.), When a writer can't write (pp. 119-133). New York: Guilford.

Bonifacci, P., Candria, L., \& Contento, S. (2008). Reading and writing: What is the relationship with anxiety and depression? Reading and Writing, 21(6), 609-625. https://doi.org/10.1007/s11145-007-9078-6Brand, A. G., \& Powell, J. L. (1986). Emotions and the writing process: A description of apprentice writers. Journal of Educational Research, 79, 280-285.

Brand, A. G., \& Powell, J. L. (1986). Emotions and the Writing Process: A Description of Apprentice Writers. The Journal of Educational Research, 79(5), 280-285. https://doi.org/10.1080/00220671.1986.10885692

Çakmak, E., \& Civelek, F. (2013). The effect of argumentative writing instruction on critical thinking tendency and writing anxiety of pre-service teachers. GUJGEF, 33 (2), 355-371.

Cocuk, H. E., Yanpar, Y. T., \& Ozer, O. (2016). The relationship between writing anxiety and writing disposition among secondary school students. Eurasian Journal of Educational Research, 63, 335-352.

https://doi.org/10.14689/ejer.2016.63.19 
Daly, J. A. (1978). Writing apprehension and writing competency. Journal of Educational Research, 72(1), 10-14. https://doi.org/10.1080/00220671.1978.10885110

Daly, J. A. (1985). Writing apprehension. In M. Rose (Ed.), When a writer can't write (pp. 43-82). New York: Guilford.

Daly, J. A., \& Miller, M. D. (1975). The empirical development of an instrument to measure writing apprehension. Research in the Teaching of English, 9, 242-49.

Erdogan, O. (2017). The Effect of Cooperative Writing Activities on Writing Anxieties of Prospective Primary School Teachers. International Journal of Research in Education and Science, 560-560. https://doi.org/10.21890/ijres.328085

Espin, C. A., Weissenburger, J. W., \& Benson, B. J. (2004). Assessing the writing performance of students in special education. Exceptionality, 12 (1), 55-66. https://doi.org/10.1207/s15327035ex1201_5

Frank Webb, A., Vandiver, B. J., \& Jeung, S. (2016). Does Completing an Enriched Writing Course Improve Writing Self-Efficacy of Talented Secondary Students? Gifted Child Quarterly, 60(1), 47-62. https://doi.org/10.1177/0016986215605359

Grabe, W., \& Kaplan, R. B. (1996). Theory and practice of writing: An applied linguistic perspective. London: Longman.

Güneyli, A. (2016). Analyzing writing anxiety level of Turkish cypriot students. Egitim ve Bilim, 4l(183), 163-180. https://doi.org/10.15390/EB.2016.4503

Hakkoymaz, S. (2017). Eğitim fakültesi öğrencilerinin eleştirel düşünme eğilimleri ile yazma kaygıları arasındaki ilişki. Ihlara Journal of Educational Research, 2(2), 24-38.

Hayes, J. (1996). A new framework for understanding cognition and affect in writing. In: C.

Hayes, J., \& Flower, L. (1980). Identifying the organisation of writing processes. In L. Gregg \& E. R. Steinberg (Eds.), Cognitive processes in writing (pp. 3-30). Hillsdale, N.J.: Erlbaum.

Huerta, M., Goodson, P., Beigi, M., \& Chlup, D. (2017). Graduate students as academic writers: writing anxiety, self-efficacy and emotional intelligence. Higher Education Research and Development, 36(4), 716-729. https://doi.org/10.1080/07294360.2016.1238881

İşeri, K., \& Ünal, E. (2012). Türkçe öğretmen adaylarının kaygı durumlarının çeşitli değişsenler açısından incelenmesi. Mersin Üniversitesi Ĕ̈itim Fakültesi Dergisi, 8(2), 67-76.

Karahan, B. Ü. (2017). The relationship between writing anxieties and writing habits of Tukish teacher candidates. Insan ve Toplum Bilimleri Araştırmaları Dergisi, 6(5), 3065-3075.

Karakaya, İ., \& Ülper, H. (2011). Yazma Kaygısı Ölçeğinin Geliştirilmesi ve Yazma Kaygısının Çeşitli Değişkenlere Göre İncelenmesi, Kuramdan Uygulamaya Eğitim ve Bilim, 11(2), 691-708.

Kaur, R., Singh, T., \& Kumar, R. S. (2012). The Relationship of Writing Apprehension Level and Self-efficacy Beliefs on Writing Proficiency Level among Pre-university Students. English Language Teaching, 5(7). https://doi.org/10.5539

Martinez, C. T., Kock, N., \& Cass, J. (2011). Pain and Pleasure in Short Essay Writing: Factors Predicting University Students' Writing Anxiety and Writing Self-Efficacy. Journal of Adolescent \& Adult Literacy, 54(5), 351-360. https://doi.org/10.1598/JAAL.54.5.5

McCutchen, D. (2000). Knowledge, processing, and working memory: Implications for a theory of writing. Educational Psychologist, 35(1), 13-23. https://doi.org/10.1207/S15326985EP3501_3

Michael, L., \& Sarah, R. (eds.), The Science of Writing: Theories, Methods, Individual Differences, and Applications , 1-27. Mahwah, NJ: Erlbaum.

Pajares, F., \& Valiante, G. (1999). Grade level and gender differences in the writing self-beliefs of middle school students. Contemporary Educational Psychology, 24, 390-405. https://doi.org/10.1006/ceps.1998.0995

Pajares, F. (2003). Self-efficacy beliefs, motivation, and achieve -ment in writing: A review of the literature. Reading \& Writing Quarterly: Overcoming Learning Difficulties, 19, 139-158. https://doi.org/10.1080/10573560308222

Pajares, F., \& Johnson, M. J. (1996). Self-efficacy beliefs and the writing performance of entering high school students. Psychology in the Schools, 33(April 1995), 163-175. https://doi.org/10.1002/(SICI)1520-6807(199604)33:2<163::AID-PITS10>3.0.CO;2-C

Pajares, F., Johnson, M. J., \& Usher, E. L. (2007). Sources of writing self-efficacy beliefs of elementary, middle, and 
high school students. Research in the Teaching of English, 42(1), 104-120.

Prat-Sala, M., \& Redford, P. (2012). Writing essays: Does self-efficacy matter? The relationship between self-efficacy in reading and in writing and undergraduate students' performance in essay writing. Educational Psychology. https://doi.org/10.1080/01443410.2011.621411

Prior, P. (2006). A sociocultural theory of writing. In C. A. MacArthur, S. Graham and J. Fitzgerald (Ed.). Handbook of writing research (pp. 54-66). New York: Guilford Press.

Salovey, P., \& Haar, M. D. (1990). The efficacy of cognitive-behavior therapy and writing process training for alleviating writing anxiety. Cognitive Therapy and Research, 14(5), 513-526. https://doi.org/10.1007/BF01172971

Schunk, D. H. (2003). Self-Efficacy for Reading and Writing: Influence of Modeling, Goal Setting, and Self-Evaluation. Reading \& Writing Quarterly, 19(2), 159-172. https://doi.org/10.1080/10573560308219

Schunk, D. H., \& Pajares, F. (2002). The development of academic self-efficacy. In A. Wigfield \& J. S. Eccles (Eds.), Development of achievement motivation (pp. 15-31). San Diego, CA: Academic Press. https://doi.org/10.1016/B978-012750053-9/50003-6

Selfe, C. L (1985). An apprehensive writer composes. In M. Rose (Ed.), When a writer can't write (pp. 83-95). New York: Guilford.

Stewart, G., Seifert, T. A., \& Rolheiser, C. (2015). Anxiety and self-efficacy's relationship with undergraduate students' perceptions of the use of metacognitive writing strategies. The Canadian Journal for the Scholarship of Teaching and Learning, 6 (1), 19. https://doi.org/10.5206/cjsotl-rcacea.2015.1.4

Topuzkanamış, E. (2015). Yazma stratejileri öğretiminin Türkçe öğretmenliği birinci sınıf öğrencilerinin yazma kaygisina etkisi. Journal of Language and Literature Education, 13, 97-110.

Woodrow, L. (2011). College English writing affect: Self-efficacy and anxiety. System, 39, 510-522. https://doi.org/10.1016/j.system.2011.10.017

Yusuf, M. (2011). Investigating relationship between self-efficacy, achievement motivation, and self-regulated learning strategies of undergraduate Students: A study of integrated motivational models. Procedia-Social and Behavioral Sciences. https://doi.org/10.1016/j.sbspro.2011.04.156

Zimmerman, B. J., \& Risemberg, R. (1997). Becoming a self-regulated writer: A social cognitive perspective. Contemporary Educational Psychology, 22(1), 73-101. https://doi.org/10.1006/ceps.1997.0919

Zorbaz, K. Z. (2011). Yazma kaygısı ve yazma kaygısının ölçülmesi. E-Journal of NewWorld Sciences Academy, 6(3), 2271-2280.

\section{Copyrights}

Copyright for this article is retained by the author(s), with first publication rights granted to the journal.

This is an open-access article distributed under the terms and conditions of the Creative Commons Attribution license which permits unrestricted use, distribution, and reproduction in any medium, provided the original work is properly cited. 